\title{
The age structure and sex ratio in wild boar (Sus scrofa) populations as determined by observations of free-roaming populations and by harvests of collective hunts in southern Poland
}

\author{
Dorota Merta • Bogusław Bobek • Marzena Albrycht • \\ Jakub Furtek
}

Received: 4 July 2014 /Revised: 23 September 2014 / Accepted: 24 September 2014 /Published online: 8 October 2014

(C) The Author(s) 2014. This article is published with open access at Springerlink.com

\begin{abstract}
Wild boars shot during collective hunts, where there are no limitations pertaining to sex and age of the harvested animals, may properly represent the sex and age structure of the population. Thus, the objective of the presented study was to compare sex and age structures evaluated via the results of collective hunts, with those based on direct observations between December 2009 and January 2010, in the large complex of the Bory Dolnoślaskie forest (BD) and in the farmland-forest mosaic of the Lasy Ślaskie forest (LS). There were no significant differences between the sex and age structures of the population determined via observations and those based on harvests collected in both the $\mathrm{BD}$ forest and the LS forest. It was shown that the age and sex structure in the wild boar population assessed purely on the basis of observation was significantly different between the BD forest and the LS forest. The calculated differences in the age and sex structures for the wild boar harvested in the study areas were also significant. It is suggested that the age and sex structure of wild boars harvested in collective hunts should be certified by using data from direct observations of free-rooming wild boar populations.
\end{abstract}

Keywords Piglets · Yearlings · Adults · Two forest habitats

\section{Introduction}

Reproduction and survival of a wild boar population is shaped by the quality and availability of the food supply (Santos et al.

Communicated by C. Gortázar

D. Merta $(\triangle) \cdot$ B. Bobek $\cdot$ M. Albrycht $\cdot$ J. Furtek

Department of Ecology, Wildlife Research and Ecotourism, Institute

of Biology, Pedagogical University of Kraków, Podbrzezie 3,

31-054 Kraków, Poland

e-mail: dorota-zbl@o2.p1
2006; Fruzinski 1992), hiding and thermal cover (FernandezLlario 2004), climate (Melis et al. 2006), weather conditions (Geisser and Reyer 2005) large predators (Nores et al. 2008), and hunting (Rusakov and Timofeev 1984; Braga et al. 2010; Keuling et al. 2013). As particular, age classes of wild boars differ in fertility and rates of survival (Gethöffer et al. 2007; Toïgo et al. 2007; Briedermann 2009); developing an adaptive harvest strategy of wild boar requires not only a reliable population census but also on knowledge of the age and sex structure of the population (Bieber and Ruf 2005; Servanty et al. 2011).

The sex ratio and age structure of the wild boar population can be adequately reflected by direct observations of the animals in their habitats, provided that the sampling is well distributed over time and space. This should be the same for animals shot during collective hunts.

For this reason, the presented study attempts to compare the sex and age structure of wild boar populations found on the basis of observations and the results of collective hunts in two different living habitats of these animals. We hypothesized that sex and age structure estimated on the basis of observation and the harvest do not differ significantly in each of the two studied habitats, and that the results of collective hunts and observation data properly represent the differences in sex and age structures between the populations living in the studied habitats.

\section{Study area}

The studies were conducted in two lowland forest habitats located in southwestern Poland. Data were collected within a solid forest complex - part of the Bory Dolnośląskie forest (BD) and in the Lasy Śląskie forest (LS) - where small forest complexes predominate, surrounded by farmlands (Table 1). 
Table 1 Description of the study areas. Based upon forest management plan for forest districts: Bolesławiec, Pieńsk, Rudziniec, Ruszów, Świętoszów, and Węgliniec. Wild boar density after Bobek et al. 2012, Unpublished Game Management Report from Rudziniec Forest District, March 2009

\begin{tabular}{lll}
\hline Study area & Bory Dolnośląskie forest & Lasy Śląskie forest \\
\hline Size of study area $\left(\mathrm{km}^{2}\right)$ & 780 & 559 \\
Area covered by forest $\left(\mathrm{km}^{2}\right)$ & 680 & 204 \\
Main forest type & Coniferous, mixed coniferous & Deciduous, mixed deciduous \\
Cereal crops in farmland $(\%)$ & 22.4 & 65.7 \\
Wild boar density $\left(\mathrm{N} / 10 \mathrm{~km}^{2}\right)$ of forest & 22.2 & 45.0 \\
Forest-farmland ecotone $\left(\mathrm{km} / 10 \mathrm{~km}^{2}\right)$ & 0.46 & 3.30 \\
\hline
\end{tabular}

The farmlands adjacent to the BD are small holdings with various types of agricultural production. The landscape of LS is dominated by large farms which focus on intensive cereal crop production. Characteristics of both study areas are given in Table 1.

\section{Material and methods}

\section{Data collection}

In both study areas, collective hunts were carried out from October 2009 to January 2010 by various groups, each made up of between 10 and 15 hunters and between 8 and 12 beaters with several dogs. Driving areas ranged from 70 to 100 ha. In the collective wild boar hunts, the hunters were allowed to shoot at any individual sighted, irrespective of their age and sex.

The age of harvested animals $(n=357)$ was determined after assessing the degree of tooth eruption and wear and tear of teeth of the lower jaw (Briedermann 2009). Three age classes were considered: piglets - under 12 months old, yearlings-between 12 and 24 months, and adults-over 24 months old.

The observations of free-roaming wild boar were conducted in the same place where collective hunts were carried out.
Data were collected in the mornings and evenings on three consecutive days in each month from October 2008 to January 2009. The observations of animals were completed using $10 \times$ 50 binoculars, when walking on linear transects arranged regularly in the study areas, as well as stationary observations made from high seats. During observations, the size of sighted groups of wild boars, as well as single individuals, were recorded. The age of the observed wild boars were determined arbitrarily on the basis of body size and mass. The animals monitored were divided into piglets, yearlings, and adults (see criteria above). Only in adults was the sex distinguished on the basis of the differences in silhouette, proportions of body parts, and the presence of secondary sexual characteristics (males). In the BD forest, 501 wild boars were recorded during 432 man-hours of observations, while in the LS forest, 611 animals were sighted during 144 man-hours of observations.

Data analysis

The results of the observations on the age and sex structure in the free-roaming population of wild boars were taken into account in further calculations, when the observed group of wild boars with the same number and age structure or a single individual of a given sex and age category was sighted only once in a given three-day period in the same observation
Table 2 Age and sex structure of wild boar population as determined by observation and harvest data collected from October 2008 and January 2009 in southwestern Poland

\begin{tabular}{|c|c|c|c|c|c|c|}
\hline Study areas & & Piglets & Yearlings & Adult females & Adult males & Total \\
\hline \multirow[t]{6}{*}{ Bory Dolnośląskie forest } & \multicolumn{6}{|c|}{ Animals observed } \\
\hline & $N$ & 186 & 146 & 64 & 40 & 436 \\
\hline & $\%$ & 42.7 & 33.4 & 14.7 & 9.2 & 100.0 \\
\hline & \multicolumn{6}{|c|}{ Animals harvested } \\
\hline & $N$ & 64 & 57 & 30 & 15 & 166 \\
\hline & $\%$ & 38.6 & 34.3 & 18.1 & 9.0 & 100.0 \\
\hline \multirow[t]{6}{*}{ Śląskie forest } & \multicolumn{6}{|c|}{ Animals observed } \\
\hline & $N$ & 280 & 109 & 61 & 27 & 477 \\
\hline & $\%$ & 58.7 & 22.8 & 12.8 & 5.7 & 100.0 \\
\hline & \multicolumn{6}{|c|}{ Animals harvested } \\
\hline & $N$ & 102 & 46 & 28 & 15 & 191 \\
\hline & $\%$ & 53.4 & 24.1 & 14.6 & 7.9 & 100.0 \\
\hline
\end{tabular}


place. When there were repeated sightings, only one of them was recorded for further calculations. Statistical analyses were performed using the $\chi^{2}$ test (Sokal and Rohlf 1995).

\section{Results and discussion}

In the BD forest, the percentage of piglets among observed wild boar $(n=436)$ was $42.7 \%$, whereas among harvested wild boars, it was $38.6 \%$. Among the animals harvested, there were higher proportions of yearlings and adult females, whereas the proportion of adult males was lower than that among the observed wild boars (Table 2). Adult females and males constituted $23.8 \%$ of the sighted wild boars and $27.1 \%$ of the wild boars harvested.

In the LS forest, piglets constituted $58.7 \%$ of all wild boars observed $(n=477)$ and $53.4 \%$ of the wild boars harvested. Among the wild boars sighted in this forest, the proportions of the remaining categories of sex and age were higher than the corresponding figures among the wild boars harvested (Table 2). Adult females and males constituted $18.4 \%$ of the observed animals and $22.5 \%$ of the harvested wild boars.

There was a lack of significant differences between the sex and age structures of the population determined via observations and those based on harvests of collective hunts in both the $\mathrm{BD}$ forest $\left(\chi^{2}=1.4031 ; p=0.7048\right)$ and the $\operatorname{LS}$ forest $\left(\chi^{2}=\right.$ $2.1602 ; p=0.5398)$. It was shown that the age and sex structure in the wild boar populations assessed purely on the basis of observation were significantly different between the BD forest and the LS forest $\left(\chi^{2}=25.1338 ; p=0.001\right)$. The calculated differences in the age and sex structures for the wild boar harvested in the study areas were also significant $\left(\chi^{2}=8.2322\right.$; $p=0.041$ ) (Table 2).

Nevertheless, it can be stated that in both of the two study areas, the proportion of piglets observed in free-roaming populations was slightly higher than in the hunting bags, whereas the proportion of yearlings was slightly lower than those among the animals harvested. Perhaps, this is a result of the smaller body size of piglets compared with yearlings and adults, which reduces the probability of them being shot by hunters. It also cannot be excluded that some hunters are only interested in getting trophy specimens and therefore do not shoot any animal, but selectively choose individuals of larger sizes.

Recently, throughout Europe, a dynamic increase in the number of wild boars has been observed (Apollonio et al. 2010). For this reason, if the proportion of piglets is lower than that of yearlings among animals harvested in collective hunts (Boitani et al. 1995; Fernández-Llario and Mateos-Quesada 2003; Massolo and Mazzoni Della Stella 2006), the age and sex structure of animals harvested does not represent these parameters in free-roaming populations. However, if the results of collective hunts show a higher proportion of piglets than yearlings (Fernández-Llario et al. 2003; Moretti 1995; Durio et al. 1995; Braga et al. 2010), it is very probable that the structure of animals harvested reflects, to various degrees, the proportions of particular categories of sex and age in the free-roaming population; however, the data should still be verified by direct observations.

Discussions during the 10th International Symposium on Wild Boar and other Suids demonstrated that there are significant differences in the criteria for permitting the harvest of wild boars based on sex and age categories, and that these norms are often rooted only in long-time traditions (Cellina 2014). Therefore, in some cases, the age and sex structure of bagged wild boars may not necessarily represent the structure of free-roaming population. So, we suggest that the research in various regions of Poland, as well as in other countries of Europe on age and sex structure of wild boar populations should be intensified, and, in parallel with the analysis of bags in collective hunts, observations of free-roaming populations should be continued.

Acknowledgments The authors extend their warm thanks to Forest Service in the Bory Dolnoślaskie forest and Lasy Śląskie forest for their help in the observation of free-living wild boar population. For helpful comments on an early draft of this manuscript, we thank Professor Paul R. Krausman.

Open Access This article is distributed under the terms of the Creative Commons Attribution License which permits any use, distribution, and reproduction in any medium, provided the original author(s) and the source are credited.

\section{References}

Apollonio M, Andersen and Putman R (eds) (2010) European ungulates and their management in the 21st century. Cambridge, United Kingdom, Cambridge University Press, Cambridge

Bieber C, Ruf T (2005) Population dynamics in wild boar Sus scrofa: ecology, elasticity of growth rate and implications for the management of pulsed resource consumers. J Appl Ecol 42(6):1203-1213

Bobek B, Merta D, Furtek J (2012) The dynamics of wild boar population numbers in the lowland forests of south-western Poland. Abstracts of 9th International Symposium on wild boar and other Suids, Hannover, p 39

Boitani L, Trapanese P, Matei L, Nonis D (1995) Demographic of a wild boar population in Tuscany, Italy. Gib Faun Sauv Game Wildl 12: 109-132

Braga C, Alexandre N, Fernández-Llario P, Santos P (2010) Wild boar (Sus scrofa) harvesting using the espera hunting method: side effects and management implications. Eur J Wildl Res 56(3):465-469

Briedermann L (2009) Schwarzwild. Kosmos Verlag, Stuttgart

Cellina S (2014) Dos and don'ts in European wild boar (Sus scrofa) management or: why can't we agree on releasing, feeding, poisoning, trapping, shooting 24/7 ... Book of Abstract of 10th Symposium on wild Boar and other Suids, Velenje, Slovenia, September 1-5, 2014:14 
Durio P, Gallo-Orsi U, Macchi E, Perrone A (1995) Structure and monthly birth distribution of a wild boar population living in a mountainous environment. J Mount Ecol Ibex 3:202-203

Fernandez-Llario P (2004) Environmental correlates of nest site selection by wild boar Sus scrofa. Acta Theriol 49(3):383-392

Fernández-Llario P, Mateos-Quesada P (2003) Population structure of wild boar (Sus scrofa) in two Mediterranean habitats in the western Iberian Peninsula. Folia Zool 52(2):143-148

Fernández-Llario P, Mateos-Quesada P, Silverio A, Santos P (2003) Habitat effects and shooting techniques on two wild boar (Sus scrofa) populations in Spain and Portugal. Zeitschrift fur Jagdw 49(2):120-129

Fruzinski B (1992) Wild boar. Cedrus, Warsaw

Geisser H, Reyer H (2005) The influence of food and temperature on population density of wild boar Sus scrofa in the Thurgau (Switzerland). J Zool Lond 267:89-96

Gethöffer F, Sodeikat G, Pohlmeyer K (2007) Reproductive parameters of wild boar Sus scrofa in three different parts of Germany. Eur J Wildl Res 53:287-297

Keuling O, Baubet E, Duscher A, Ebert C, Fischer C, Monaco A, Podgórski T, Prevot C, Ronnenberg K, Sodeikat G, Stier N, Thurfjell H (2013) Mortality rates of wild boar Sus scrofa L. in central Europe. Eur J Wildl Res 59(6):805-814

Massolo A, Mazzoni Della Stella R (2006) Population structure variations of wild boar Sus scrofa in central Italy. Ital J Zool 73(2):137-144
Melis C, Szafrańska PA, Jędrzejewska B, Bartoń K (2006) Biogeographical variation in the population density of wild boar Sus scrofa in western Eurasia. J Biog 33(5):803-811

Moretti M (1995) Birth distribution, structure and dynamics of a hunted mountain population of wild boar (Sus scrofa L.), Ticino, Switzerland. Ibex J Mount Ecol 3:192-196

Nores C, Llaneza and Alvaeez MA (2008) Wild boar Sus scrofa mortality and wolf Canis lupus predation: an example in northern Spain. Wildl Biol 14:44-51

Rusakov OS, Timofeeva EK (1984) The wild boar: ecology, resources, and economic significance in the Northwestern Soviet Union. Izdatelstvo Leningradskogo Gosudarstvennogo Universiteta, Leningrad

Santos P, Fernández-Llario P, Fonseca C, Monzón A, Bento P, Soares A, Mateos-Quesada P, Petrucci-Fonseca F (2006) Habitat and reproductive phenology of wild boar (Sus scrofa) in the western Iberian Peninsula. Eur J Wildl Res 52(3):207-212

Servanty S, Gaillard JM, Ronchi F, Focardi S, Baubet E, Gimenez $\mathrm{O}$ (2011) Influence of harvesting pressure on demographic tactics: implications for wildlife management. J Appl Ecol 48:835-843

Sokal RR, RohlfFJ (1995) Biometry - the principles and practice of statistics in biological research. WH Freeman and Company, New York

Toïgo C, Servanty S, Gaillard JM, Brandt S, Baubet E (2007) Disentangling natural from hunting mortality in an intensively hunted wild boar population. J Wildl Manag 72(7):1532-1538 